\title{
The Effect of YouTube eWOM on Consumer Buying Interest *
}

\author{
El efecto del boca a boca electrónico en el interés de compra de los \\ consumidores
}

\author{
Amar Nuriman Izudin \\ Master in Management, Esa Unggul University, \\ Tangerang, Indonesia, amar.nuriman@gmail.com \\ Endang Ruswanti \\ PhD in Management, Esa Unggul University, \\ Tangerang, Indonesia, endang.ruswanti@esaunggul.ac.id \\ Moehammad Unggul Januarko \\ PhD in Management, Esa Unggul University, \\ Tangerang, Indonesia, unggul@esaunggul.ac.id
}

How to cite / Cómo citar

Nuriman Izudin, A.; Ruswanti, E.; Unggul Januarko, M. (2020). The Effect of YouTube eWOM on Consumer Buying Interest. Revista CEA, v. 6, n. 12, 167-179. https://doi.org/10.22430/24223182.1618

Received: 8 March 2020

Accepted: 1 June 2020

\begin{abstract}
YouTube creates valuable social media opportunities in eWOM content. Individuals currently discuss products and other matters with their friends and new acquaintances over the internet. The purpose of this study was to determine the effect of YouTube eWOM conversations on consumer buying interest. Based on the Information Adoption Model (AIM) and the Theory of Reasoned Action (TRAM), we developed a new conceptual model: The Information Acceptance Model (IACM). In this quantitative study, the population under analysis, composed of followers of a YouTube channel, was selected using purposive sampling so that the number of respondents was 200 . We implemented data analysis techniques using the Structural Equation Model with Lisrel. The results show that information quality, information credibility, information needs, information usefulness, information adoption, and attitude towards information influence consumer buying interest.
\end{abstract}

Keywords: e-WOM, YouTube, Consumer Buying Interest.

* This article is derived from the project entitled "The Effect of YouTube eWOM on Consumer Buying Interest" and has been financed with Indonesian government resources. 
JEL Classification: L66, L82, M31, M32.

\section{Resumen}

YouTube crea oportunidades valiosas para las redes sociales con el boca a boca electrónico (eWOM en inglés). Las personas ahora hablan de productos y otros asuntos con sus amigos y nuevos conocidos en internet. El objetivo de este estudio es determinar el efecto del boca a boca electrónico en conversaciones en YouTube sobre el interés de compra de los consumidores. Basado en el Modelo de Adopción de Información y la Teoría de la Acción Razonada, se desarrolló el Modelo de Aceptación de Información. El método de esta investigación fue de carácter cuantitativo. La población analizada estuvo compuesta por los seguidores de un canal de YouTube y se seleccionó usando muestreo intencional. Se implementaron técnicas de análisis de datos usando el Modelo de Ecuaciones Estructurales del paquete Lisrel. Los resultados muestran que la calidad, credibilidad, necesidad, utilidad y adopción de la información, así como la actitud hacia la misma, influencian el interés de compra de los consumidores.

Palabras clave: eWOM, YouTube, interés de compra.

Clasificación JEL: L66, L82, M31, M32.

\section{INTRODUCTION}

Electronic Word of Mouth (eWOM) has long been considered an influential marketing instrument (Bickart \& Schindler, 2001; Kumar \& Benbasat, 2006). Consumers look for information posted by previous customers so that they feel comfortable before buying a product (Pitta \& Fowler, 2005). The internet has provided several platforms suitable for eWOM such as blogs, discussion forums, review websites, shopping sites, and social media websites (Cheung \& Thadani, 2012; Doi \& Hayakawa, 2020). Through social media, individuals can share their comments using text, images, videos, and applications. Visually enriched content makes eWOM more fun and interesting. In turn, social media facilitates the dissemination of eWOM information among large numbers of people (Sohn, 2014) and enables users to share their thoughts by forwarding posts that they approve (Chu \& Kim, 2011; Babić Rosario et al., 2020). For this reason, consumers increasingly use social media to obtain brand information (Heller Baird \& Parasnis, 2011; Barreda et al., 2015; Naylor et al., 2012).

YouTube's social media platform, a relatively new eWOM, has brought a new aspect to eWOM that allows users to communicate with their network (Baek et al., 2017). Individuals can now exchange opinions and experiences about products with friends and acquaintances on social media (Chu \& Kim, 2011; Kozinets et al., 2010). One of the main advantages of YouTube is that all of its content is in the form of videos that are easily watched compared to other more traditional social media such as print, radio, and television (Viertola, 2018; Hashim \& Ariffin, 2016).

YouTube allows individuals from all over the world to interact, collaborate, and share content in the form of words, images, videos, or sounds that present ideas, opinions, and testimonials about their experiences (Schwemmer \& Ziewiecki, 2018). Hsu y Tsou (2011) stated that blog recommendations /online reviews have a direct effect on attitude and an indirect effect on consumer buying interest. This study integrates the Information Adoption Model (IAM) and components related to the Theory 
of Reasoned Action. The IAM explains the characteristics of eWOM information, and the components of the TRA explain consumer behavior towards WOM information. The purpose of this study is to examine the effect of YouTube eWOM on consumer purchase intentions mediated by location. To achieve this goal, we used the Information Acceptance Model (IACM).

Specifically, the IACM tests quality, credibility, usefulness and adoption of information, information needs, and attitudes towards information as the main precursors of buying interest. These results provide theoretical insights about eWOM on YouTube and contribute the models presented here to the literature. On the managerial side, understanding that the determinants of eWOM information on YouTube influence consumer buying interests can help marketers utilize eWOM in their digital marketing activities. The importance of YouTube for consumer buying interest was pointed out by Yuksel (2016), who identified the factors that influence consumer purchase intentions. He analyzed YouTube videos about products and several factors that influence purchase intentions at different levels.

The credibility and popularity of content about a product can be measured by the number of posted comments, which can influence purchase intentions (Lee, 2009), as well as the number of likes and views (Mir \& Rehman, 2013). eWOM information on social media can appear in a number of different ways. Users can intentionally post about their product brand. Furthermore, users can accidentally display preferences to their network, such as being fan of a brand, interacting with several brand posts via likes and comments, or posting content that includes brands without advertising purposes. Finally, marketers can also post information through their official social media accounts (Alboqami et al., 2015). Users of eWOM need comprehensive information to establish their consumer buying interest.

The Information Adoption Model has four components: argument quality (central route), source credibility (peripheral route), usefulness of information, and adoption of information. With this integration, IAM can explain how people are affected by information on a computer-mediated communication platform. The Theory of Reasoned Action connects beliefs, attitudes, intentions, and behavior. Willingness is the best predictor of behavior, which means that the best way to know what someone will do is to know that person's willingness. However, one can make judgments based on completely different reasons (not always on willingness). An important concept in this theory is the focus of attention (salience), that is, considering that something is important. Intention is determined by subjective attitudes and norms (Hartono, 2007). The Information Acceptance Model (IACM), as explained above, extends the IAM (Sussman \& Siegal, 2003) by integrating TRA-related components (Fishbein \& Ajzen, 1975). The IAM explains the characteristics of eWOM information, while the related components of TRA represent consumer behavior towards eWOM information. With this integration, this research model can bring the IAM one step forward. The current version of the IAM only explains information adoption, while the IACM expands the idea of information adoption by including consumer behavior and explains how this process influences behavioral intentions. Finally, the IACM examines the relationship between several variables (information quality, information credibility, information needs, attitude towards information, usefulness of information, and adoption of information) and buying interest. 


\section{Buying interest}

The interest in buying something, a psychological attraction that exists in an individual's mind, has an impact on taking action (Schiffman \& Kanuk, 2010). According to Ferdinand in Faikar Annafik and Rahardjo, (2012), buying interest can be identified through three indicators: (1) transactional intention, namely, the tendency of someone to buy a product; (2) referential intention, namely, the tendency of someone to refer the product to others; and (3) preferential intentions, namely, interests that describe the behavior of someone who has a primary preference for a product. Such preference can only be replaced if something happens to the preferred product.

\section{Research hypothesis}

eWOM information has become an important factor in shaping consumer behavior. Reviews by other consumers shared in a review platform can influence consumer buying interest Furner et al., (2016), Hsu and Tsou (2011). When consumers are going to make a purchase, they usually look for information about the product beforehand. In addition to information in advertisements, consumers can also obtain information, through social media, in the form of opinions expressed by other consumers who have also used or purchased the item. Reviews posted online by other consumers can be either positive or negative opinions. The research hypotheses can be proposed:

H1. The adoption of eWOM information positively influences consumer buying interest.

Social media users, intentionally or unintentionally, are exposed to a huge amount of eWOM information, and previous studies have found such eWOM information to influence consumers' purchase intentions (See-To \& Ho, 2014; Wang et al., 2012). However, not all eWOM information posted on social media has the same effect on consumers' purchase intentions; the level of impact can vary (Yang, 2012). In this study, through linking IAM and TRA, we predict that the consumers who adopt eWOM information are more likely to have a buying interest.

H2. Information usefulness positively influences the adoption of eWOM information.

Information usefulness and information adoption, Information usefulness refers to individuals' perception that using new information will improve their performance (Bailey \& Pearson, 1983; Cheung et al., 2008). Information usefulness is considered the main predictor of information adoption (Davis, 1989; Sussman \& Siegal, 2003) and purchase intentions (Lee \& Koo, 2015) because people tend to be involved deal with information when they think it is useful. Especially on social media, people find a large amount of eWOM information (Chu \& Kim, 2011); therefore, they may have a greater intention to adopt when they find it useful.

H3. The quality of eWOM information positively influences the usefulness of eWOM information. The quality and credibility of information has now become more critical (Xu, 2014). Consumers are more excited about certain products when the information meets their needs (Olshavsky, 1985). In fact, previous researchers found that the quality of online reviews had a positive effect on consumer purchase intentions (Lee \& Shin, 2014; Park et al., 2007). Therefore, we estimate that the quality of eWOM information on social media can be a determinant of consumer purchase intentions. 
H4. The credibility of eWOM information positively influences the usefulness of eWOM information. In addition, previous research shows the relationship between information credibility, consumer purchase intentions (Nabi \& Hendriks, 2003; Prendergast et al., 2010), and information adoption (McKnight \& Kacmar, 2006). However, according to Wathen and Burkell (2002), information credibility is an initial factor in the process of individual persuasion. Therefore, based on the IAM, we estimate that the credibility of eWOM information is positively related to its usefulness in addition to information adoption and buying interest.

H5. The need for eWOM information positively influences the usefulness of eWOM information. Information needs have mainly been studied as motivators of Word of Mouth (WOM) involvement (Sundaram et al., 1998). Subsequent studies have referred to this idea as seeking advice '(HennigThurau et al., 2004; Wolny \& Mueller, 2013) and opinion search (Chu \& Kim, 2011) with different research questions. However, in this study, we added information needs to our model as the dependent variable because we anticipate that people who search for information on social media are more likely to find what can be used and adopt it. Ultimately, information needs can influence purchase intentions.

H6. Attitudes towards eWOM information positively affect the usefulness of eWOM information. Attitude towards information is another dependent variable that we added after considering the TRA (Fishbein \& Ajzen, 1975). The attitudes of consumers toward eWOM have been examined by researchers in several studies (Park et al., 2007; Prendergast et al., 2010).

H7. Attitudes toward eWOM information have a positive effect on consumer buying interest. In addition to the TRA, two more theories, the Theory of Planned Behaviour (TPB) (Ajzen, 1991) and the Technology Acceptance Model (TAM) (Davis et al., 1992), indicate there is a relationship between attitude and behavioral intention. Therefore, we hypothesized that the attitudes of social media users toward eWOM information can have a positive effect on eWOM information usefulness and consumer buying interest.

\section{METHOD}

This study applied a deductive quantitative method to answer research questions, derived from concepts or theories, that were formulated as hypotheses. We adopted a quantitative approach by using online questionnaires to explore the effects of YouTube eWOM on consumer buying interest and identify the factors influencing this relationship. The model introduced in this study, named the Information Acceptance Model (IACM), shows that the influence of eWOM on social media depends not only on the characteristics of eWOM information (such as quality and credibility) but also on consumers' attitude towards eWOM information. The IACM expands the notion of information adoption by including consumer behavior, and it explains how this process influences behavioral intention. In this study, the IACM examines the relationships between several variables: information quality, information credibility, information needs, attitude towards information, information usefulness, information adoption, and purchase intention.

The data was obtained by a survey method, collected from answered questionnaires. The latter were distributed among YouTube users. Secondary data were gathered from a review of literature related 
to this study. In this study, the universe included all the subscribers to the channel DURIAN TRAVELER on YouTube. We used purposive sampling with a sampling criterion: being subscribed to said channel. The sample was selected to meet the requirement established by Hair et al., (2010): the number of samples taken into consideration should be at least 5-10 times the number of parameters used in the study. According to Hair et al., (2010) the critical sample size for an analysis using LISREL is 200 samples. As a result, the number of samples examined in this study was also 200. The purpose of a data analysis method is to interpret and draw conclusions from collected data. We used Structural Equation Modeling (SEM) in the statistical package LISREL 9.3 to process and analyze the research data. According to Tarka (2017), SEM software can detect not only the causality relationship (direct and indirect) between the observed variables or constructs but also the loading of the components that contribute to the formation of the construct itself. Thus, the causality relationship between the variables or constructs becomes more informative, complete, and accurate.

\section{RESULTS}

\section{Analysis of Respondents' Demographic Differences}

An analysis of respondents' demographic differences (sex, age, educational attainment, and income) was carried out to determine whether there were significant differences in each variable. The following table (see Table 1) analyzes respondent's profiles.

Table 1. Results Analysis of Respondents' Descriptions

Tabla 1. Análisis del perfil de los participantes

\begin{tabular}{|c|c|c|c|}
\hline Demographic variable & Classification & $\begin{array}{c}\text { Total } \\
\text { (respondents) }\end{array}$ & Percentage \\
\hline \multirow{2}{*}{ Gender } & Male & 192 & $96 \%$ \\
\hline & Female & 8 & $4 \%$ \\
\hline \multirow{4}{*}{ Age } & $17-26$ & 10 & $5 \%$ \\
\hline & $27-36$ & 91 & $45.5 \%$ \\
\hline & $37-46$ & 69 & $34.5 \%$ \\
\hline & $>46+$ & 30 & $15 \%$ \\
\hline \multirow{4}{*}{ Work } & Civil servant & 10 & $5 \%$ \\
\hline & Private Employee & 91 & $45.5 \%$ \\
\hline & Entrepreneur & 69 & $34.5 \%$ \\
\hline & Student & 30 & $15 \%$ \\
\hline \multirow{4}{*}{ Montly Expenditure } & $<\operatorname{Rp} 1.000 .000$ & 8 & $4 \%$ \\
\hline & Rp 1.000.001-Rp 3.000.000 & 16 & $8 \%$ \\
\hline & Rp 3.000.001-Rp 5.000.000 & 59 & $29.5 \%$ \\
\hline & $>\operatorname{Rp~5.000.001}$ & 117 & $58.5 \%$ \\
\hline \multirow{3}{*}{ Duration Recognize } & 0-6 months & 15 & $7.5 \%$ \\
\hline & 6 month- 1 year & 61 & $30.5 \%$ \\
\hline & $>1$ year & 124 & $62 \%$ \\
\hline \multirow{3}{*}{ Number of Purchase } & Once & 102 & $51 \%$ \\
\hline & $2-3$ times & 53 & $26.5 \%$ \\
\hline & $>3$ times & 45 & $22.5 \%$ \\
\hline
\end{tabular}




\section{Validity and Reliability}

The results of construct validity show that all the determinants of the variable can be accepted because the factor loading value is high enough $(>0.50)$ and the t-value is greater than that of the ttable (1.96) at a $5 \%$ significance level, except for the variable information quality, whose loading factor is $0.23(<0.50)$ and its t-value is 2.74 .

Furthermore, the construct reliability test meets the requirements, with construct reliability (CR) values above 0.60 and VE values above 0.50 (Hair, et al., 2013). All the construct reliability (CR) values meet the reliability requirement (above 0.60 ), and all the VE values do so as well (above 0.50 ), except for the variable information quality, with a value of VE $0.39(<0.50)$ and attitude variables related to information with a VE value of $0.44(<0.50)$.

\section{Analysis of the Models}

The analysis of all the validity tests (including the Chi-squared, ECVI, AIC and CAIC, Fit Index, and Goodness of Fit) showed good compatibility. There are close fit results with Root Mean Square Error of Approximation (RMSEA). From the results of the analysis above, it can be concluded that the fit test of all the models meets the requirements (good fit and close fit). Furthermore, in this study, we calculated the t-values in the following path diagram (see Figure 1).

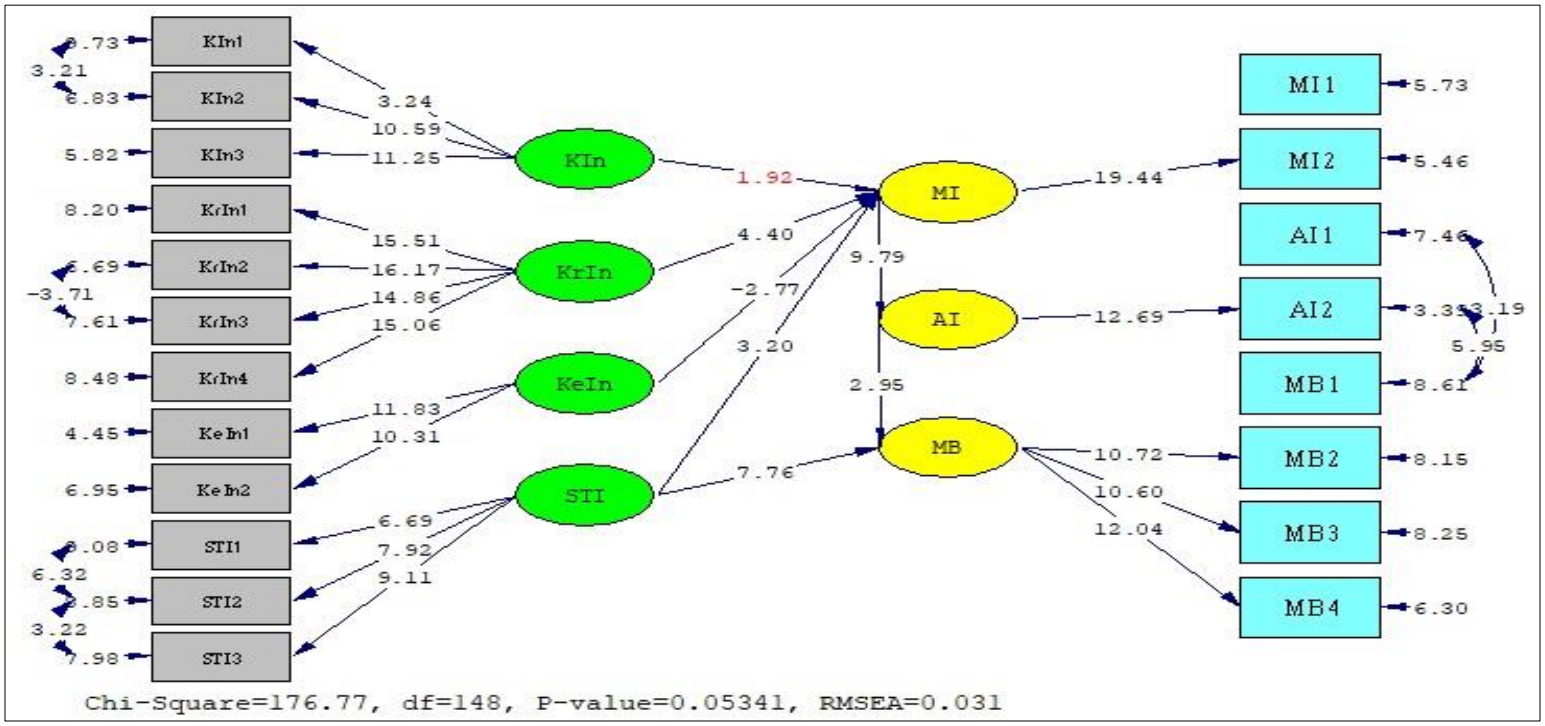

Figure 1. Path diagram with t-values

Figura 1. Diagrama de trayectorias con valores $t$ Source: Created by authors.

The models were analyzed to identify the indicators (observed variables) of each construct and calculate their reliability value. The validity of the indicators used to measure the construct of the model can be seen in the figure above. The indicator that is used must have a t-value greater than 1.96, and the value of the standard factor should be greater or equal to 0.5 (Hair et al., 2008). The test shows the accepted variable because the factor loading value has a good match (>0.50); then, the t-value is greater than the t-table (1.96) at a $5 \%$ significance level. Construction Reliability Test 
Results Model reliability can be tested using construct reliability (CR) and variance extracted (VE) calculations. According to Hair et al., (2008), good reliability is represented by CR>0.60 and VE>0.50. Based on the calculations, the variables meet the reliability requirements. All the $C R$ values meet the reliability requirements of information quality (0.63), information credibility (0.92), information needs (0.74), attitude towards information (0.60), information benefits (0.91), information adoption (0.83), and buying interest (0.86).

\section{DISCUSSION}

The results of the structural equation model show that both the characteristics of eWOM information and consumer behavior towards eWOM information have a positive impact on consumer buying interest. All the hypotheses between information quality, information credibility, information needs, attitudes towards information, usefulness of information, adoption of information, and buying interest have an effect, except between quality of information and benefits of information and attitude towards information and benefits of information.

Information quality did not have an effect on information usefulness, maybe because of the noise (interference) in communication. Noise can obscure the information received by both resenders and official recipients (Loudon \& Della, 1988 in Wu \& Newell, 2003). The result is that even quality information can be seen as poor quality, which will ultimately affect the reception of the information and the information usefulness itself. Since good information looks bad, people do not accept it or perceive its usefulness. The other hypotheses were rejected because not all the collected information was useful for all the individuals as they did not watch the same videos. The content is less comprehensive for all categories.

Other results show that information credibility has a positive effect on information usefulness. The results of this study prove that DURIAN TRAVELER, as a community of durian lovers on YouTube, always provides information from credible sources for its readers. Source credibility refers to the credibility a person perceives in an information source, regardless of the type of information. Even though source credibility is not related to the information itself, it can influence customers' perception of the information's usefulness (Di \& Luwen, 2012). The usefulness of the information perceived by customers will decrease if the source is less credible. Di and Luwen's idea is evidenced in the results of this questionnaire, in which the majority agree on the usefulness of the information shown on the YouTube channel DURIAN TRAVELER.

Furthermore, information usefulness also significantly influences information adoption, as suggested by the IAM (Sussman \& Siegal, 2003). The results of this study prove that the model suggested by Sussman \& Siegal, (2003) applies to eWOM research. Such results are also in line with those obtained by Cheung et al., (2008). This means that readers always find the information provided by the YouTube channel DURIAN TRAVELER useful; therefore, they adopt said information. This could be omitted. We also added consumer purchase intention to the evaluation as the dependent variable. Therefore, our results indicate that the process of information adoption suggested by the IAM also affects consumer purchase intention.

These results prove that the research model is significant for ewom in social media. Information needs and attitudes towards information are also among the determinants of eWOM in social media 
that affect consumer buying interest. This result is in line with other previous studies (Chu \& Kim, 2011; Park et al., 2007; Prendergast et al., 2010). From a managerial perspective, this paper provides marketers with a better marketing strategy, as well as a more efficient and effective reference framework to understand the effect of YouTube eWOM on consumer buying interest.

\section{CONCLUSIONS}

This study proposed a research model called Information Acceptance Model (IACM) to test the effect of YouTube eWOM on consumer buying interest. The IACM indicated that the influence of YouTube eWOM information does not only depend on its characteristics (such as quality and credibility) but also on consumer behavior towards eWOM information. This model was validated using a survey answered by 200 respondents who watched the YouTube channel DURIAN TRAVELER; nevertheless, information quality did not have a significant effect on information benefits. The results reveal several theoretical and managerial implications. However, the main contribution of this study is developing a comprehensive conceptual model that examines the determinants of YouTube eWOM information that affect consumer buying interest. This model was developed based on the integration of the IAM and TRA-related components.

The IAM explains the characteristics of eWOM information (Sussman \& Siegal, 2003), while the related components of TRA describes consumer behavior towards eWOM information (Fishbein \& Ajzen, 1975). However, the model presented in this study, named the Information Acceptance Model (IACM), offers a more comprehensive approach by considering consumer behavior along with the characteristics of information in the same model. Accordingly, future studies implementing the IACM should (a) offer new approaches to information adoption by expanding the IAM and providing new insights for researchers in the field of information systems; (b) further research empirically tested hypotheses in the most recent study on eWOM (Knoll et al., 2015), which presents a joint evaluation of the characteristics of eWOM information and consumer behavior towards eWOM information; and (c) improve the understanding of YouTube eWOM information by highlighting the determinants such information that affect consumer buying interest.

\section{ACKNOWLEDGMENTS}

We thank the Ministry of Research and Higher Education of the Government of Indonesia for funding this research project. We are also grateful to the anonymous peer reviewers who helped us improve the manuscript.

\section{REFERENCES}

Ajzen, J. (1991). The theory of planned behavior. Organizational Behavior and Human Decision Processes, v. 50, n. 2, 179-211. https://doi.org/10.1016/0749-5978(91)90020-T

Alboqami, H.; Al-Karaghouli, W.; Baeshen, Y.; Erkan, I.; Evans, C.; Ghoneim, A. (2015). Electronic word of mouth in social media: the common characteristics of retweeted and favourited marketergenerated content posted on Twitter. International Journal of Internet Marketing and Advertising, v. 9, n. 4, 338e358. 
Babić Rosario, A.; de Valck, K.; Sotgiu, F. (2020). Conceptualizing the electronic word-of-mouth process: What we know and need to know about eWOM creation, exposure, and evaluation. Journal of the Academy of Marketing Science, v. 48, 422-448. https://doi.org/10.1007/s11747-019-00706-1

Baek, H.; Oh, S.; Yang, H. D.; Ahn, J. (2017). Electronic word-of-mouth, box office revenue and social media. Electronic Commerce Research and Applications, v. 22, 13-23. https://doi.org/10.1016/j.elerap.2017.02.001

Bailey, J. E.; Pearson, S. W. (1983). Development of a tool for measuring and analyzing computer user satisfaction. Management Science, v. 29, n. 5, 530-545. http://doi.org/10.1287/mnsc.29.5.530.

Barreda, A. A.; Bilgihan, A.; Nusair, K.; Okumus, F. (2015). Generating brand awareness in online social networks. Computers in Human Behavior, v. 50, 600-609. http://doi.org/10.1016/j.chb.2015.03.023

Bickart, B.; Schindler, R. M. (2001). Internet forums as influential sources of consumer information. Journal of Interactive Marketing, v. 15, n. 3, 31-40. http://doi.org/10.1002/dir.1014

Cheung, C. M. K.; Lee, M. K. O.; Rabjohn, N. (2008). The impact of electronic word-of-mouth: the adoption of online opinions in online customer communities. Internet Research, v. 18, n. 3, 229247. http://doi.org/10.1108/10662240810883290

Cheung, C. M. K.; Thadani, D. R. (2012). The impact of electronic word-of-mouth communication: A literature analysis and integrative model. Decision Support Systems, v. 54, n. 1, 461-470. http://doi.org/10.1016/j.dss.2012.06.008

Chu, S. C.; Kim, Y. (2011). Determinants of consumer engagement in electronic word-of-mouth (eWOM) in social networking sites. International Journal of Advertising, v. 30, n. 1, 47-75. http://doi.org/10.2501/IJA-30-1-047-075

Davis, F. D. (1989). Perceived usefulness, perceived ease of use, and user acceptance of information technology. MIS Quarterly, v. 13, n. 3, 319-340. http://doi.org/10.2307/249008

Davis, F. D.; Bagozzi, R. P.; Warshaw, P. R. (1992). Extrinsic and Intrinsic Motivation to Use Computers in the Workplace. Journal of Applied Social Psichology, v. 22, n. 14, 111-1132. https://doi.org/10.1111/j.1559-1816.1992.tb00945.x

Di, C.; Luwen, W. (2012). Factors affecting e-WOM adoption. Unpublished bachelor thesis, Hong Kong: Hong Kong Baptist University.

Doi, N.; Hayakawa, H. (2020). Electronic word-of-mouth: a survey from an economics perspective. International Journal of the Economics of Business, v. 27, n. 2, 1-18. https://doi.org/10.1080/13571516.2020.1747853 
Faikar Annafik, A.; Rahardjo, M. (2012). Analisis pengaruh kualitas produk, harga, dan daya tarik iklan terhadap minat beli sepeda motor yamaha (Studi kasus pada konsumen Yamaha SS Cabang Kedungmundu Semarang). Diponegoro Journal of Management, v. 1, n. 4, 274-281. URL

Fishbein, M.; Ajzen, I. (1975). Belief, attitude, intention and behaviour: An introduction to theory and research. Addison-Wesley. URL

Furner, C. P.; Zinko, R.; Zhu, Z. (2016), Electronic word-of-mouth and information overload in an experiential service industry. Journal of Service Theory and Practice, v. 26, n. 6, 788-810. https://doi.org/10.1108/JSTP-01-2015-0022

Hair, J. H.; Black, W. C.; Babin, B. J.; Anderson, R. E. (2008). Multivariate Data Analysis: International Version. Prentice-Hall International Inc.

Hartono, J. (2007). Sistem Informasi Keperilakuan. Andi Offset.

Hashim, H.; Ariffin, M. F. (2016). Factors influencing electronic word of mouth (eWOM) engagement on social networking sites in Malaysia. Pertanika Journal of Social Sciences and Humanities, v. 24, special issue, 85-94. URL

Heller Baird, C. H.; Parasnis, G. (2011). From social media to social customer relationship management. Strategy \& Leadership, v. 39, n. 5, 30-37.

http://doi.org/10.1108/10878571111161507

Hennig-Thurau, T.; Gwinner, K. P.; Walsh, G.; Gremler, D. D. (2004). Electronic word-of-mouth via consumer-opinion platforms: What motivates consumers to articulate themselves on the Internet? Journal of Interactive Marketing, v. 18, n. 1, 38-52. http://doi.org/10.1002/dir.10073

Hsu, H. Y.; Tsou, H. (2011). Understanding Customer Experiences in Online Blog Environments. International Journal of Information Management, v. 31, n. 6, 510-523.

https://doi.org/10.1016/j.ijinfomgt.2011.05.003

Knoll, L. J.; Magis-Weinberg, L.; Speekenbrink, M.; Blakemore, S. J. (2015). Social Influence on Risk Perception During Adolescence. Psychological Science, v. 26, n. 5, 583-592. https://doi.org/10.1177/0956797615569578

Kozinets, R. V.; de Valck, K.; Wojnicki, A. C.; Wilner, S. J. S. (2010). Networked narratives: understanding word-of-mouth marketing in online communities. Journal of Marketing, v. 74, n. 2, 71-89. http://doi.org/10.1509/jmkg.74.2.71

Kumar, N.; Benbasat, I. (2006). The influence of recommendations and consumer reviews on evaluations of websites. Information Systems Research, v. 17, n. 4, 425-439. http://doi.org/10.1287/isre.1060.0107 
Lee, E.-J.; Shin, S. Y. (2014). When do consumers buy online product reviews? Effects of review quality, product type, and reviewer's photo. Computers in Human Behavior, v. 31, 356-366. http://doi.org/10.1016/j.chb.2013.10.050

Lee, K.-T.; Koo, D.-M. (2015). Evaluating right versus just evaluating online consumer reviews. Computers in Human Behavior, v. 45, 316-327. http://doi.org/10.1016/j.chb.2014.12.036

Lee, S. H. (2009). How Do Online Reviews Affect Purchasing Intention? African Journal of Business Management, v. 3, n. 10, 576-581. https://doi.org/10.5897/AJBM09.204

McKnight, H.; Kacmar, C. (2006). Factors of information credibility for an Internetadvice site. In Proceedings of the 39th Hawaii International conference on system sciences. Kauia, USA. http://doi.org/10.1109/HICSS.2006.181

Mir, I-A.; Rehman, K.U. (2013). Factors affecting consumer attitudes and intentions toward usergenerated product content on YouTube. Management \& Marketing, v. 8, n. 4, 637-654. URL

Nabi, R. L.; Hendriks, A. (2003). The persuasive effect of host and audience reaction shots in television talk shows. Journal of Communication, v. 53, n. 3, 527-543. http://doi.org/10.1093/joc/53.3.527

Naylor, R. W.; Lamberton, C. P.; West, P. M. (2012). Beyond the "like" button: The impact of mere virtual presence on brand evaluations and purchase intentions in social media settings. Journal of Marketing, v. 76, n. 6, 105e120. http://doi.org/10.1509/jm.11.0105

Olshavsky, R. W. (1985). Perceived quality in consumer decision making: an integratedtheoretical perspective. In J. Jacoby, \& J. C. Olson (Eds.), Perceived quality: How consumers view stores and merchandise. 3-29. Lexington Books.

Park, D.-H.; Lee, J.; Han, I. (2007). The effect of on-line consumer reviews onconsumer purchasing intention: the moderating role of involvement. International Journal of Electronic Commerce, v. 11, n. 4, 125-148. http://doi.org/10.2753/JEC1086-4415110405

Pitta, D. A.; Fowler, D. (2005). Online consumer communities and their value tonew product developers. Journal of Product \& Brand Management, v. 14, n. 5, 283-291. http://doi.org/10.1108/10610420510616313

Prendergast, G.; Ko, D.; Yin, V. Y, S. (2010). Online word of mouth and consumer purchase intentions. International Journal of Advertising, v. 29, n. 5, 687-708. http://doi.org/10.2501/S0265048710201427

Schiffman, L.; Kanuk L. (2010). Consumer Behavior. 10th Edition. Pearson Education.

Schwemmer, C.; Ziewiecki, S. (2018). Social Media Sellout: The Increasing Role of Product Promotion on YouTube. Social Media+ Society, v. 4, n. 3. https://doi.org/10.1177/2056305118786720 
See-To, E. W. K.; Ho, K. K. W. (2014). Value co-creation and purchase intention insocial network sites: the role of electronic word-of-mouth and trust a theoretical analysis. Computers in Human Behavior, v. 31, n. 1, 182e189. http://doi.org/10.1016/j.chb.2013.10.013

Sohn, D. (2014). Coping with information in social media: the effects of network structure and knowledge on perception of information value. Computers in Human Behavior, v. 32, 145-151. http://doi.org/10.1016/j.chb.2013.12.006

Sundaram, D. S.; Kaushik, M.; Webster, C. (1998). Word of mouth communications: a motivational analysis. Advances in Consumer Research, v. 25, 527-531.

Sussman, S. W.; Siegal, W. S. (2003). Informational influence in organizations: An integrated approach to knowledge adoption. Information systems research, v. 14, n. 1, 47-65. https://doi.org/10.1287/isre.14.1.47.14767

Tarka, P. (2017). An overview of structural equation modeling: its beginnings, historical development, usefulness and controversies in the social sciences. Quality \& Quantity, v. 52, n. 1, 313-354. https://doi.org/10.1007/s11135-017-0469-8

Viertola, M. (2018). To what extent does YouTube marketing influence theconsumer behaviour of a young target group. $\underline{\mathrm{URL}}$

Wang, X.; Yu, C.; Wei, Y. (2012). Social media peer communication and impacts on Purchase intentions: a consumer socialization framework. Journal of Interactive Marketing, v. 26, n. 4, 198-208. http://doi.org/10.1016/i.intmar.2011.11.004

Wathen, C. N.; Burkell, J. (2002). Believe it or not: factors influencing credibility onthe web. Journal of the American Society for Information Science and Technology, v. 53, n. 2, 134-144. http://doi.org/10.1002/asi.10016

Wolny, J.; Mueller, C. (2013). Analysis of fashion consumers' motives to engage inelectronic word-ofmouth communication through social media platforms. Journal of Marketing Management, v. 29, n. 5-6, 562-583. http://doi.org/10.1080/0267257X.2013.778324

Wu, B. T; Newell, S. J. (2003). The Impact of Noise on Recall of Advertisements. Journal of Marketing Theory and Practice, v. 11, n. 2, 56-65. https://doi.org/10.1080/10696679.2003.11658496

Xu, Q. (2014). Should i trust him? the effects of reviewer profile characteristics on eWOM credibility. Computers in Human Behavior, v. 33, 136-144. http://doi.org/10.1016/i.chb.2014.01.027

Yang, T. (2012). The decision behavior of Facebook users. Journal of Computer Information Systems, v. 52, n.3, 50-59. URL

Yuksel, H. F. (2016). Factors Affecting Purchase Intention in Youtube Videos. The Journal of Knowledge Economy \& Knowledge Management, v. 11, n. 2, 33-47. URL 